\title{
The Importance of Reproductive Health / Sexual Health Education in Adolescents
}

\author{
Vasfiye Bayram Değer ${ }^{1 *}$, PhD, Elçin Balcı $\mathrm{Dr}^{2}$ \\ ${ }^{1}$ Assistant Professor, Nursing Department, Mardin Artuklu University School of Health, Mardin/TURKEY \\ ${ }^{2}$ Associate Professor, Public Health Department, Erciyes University of Medical Faculty
}

Submission: July 27, 2018; Published: August 07, 2018

*Corresponding author: Vasfiye Bayram Değer, PhD, Assistant Professor, Nursing Department, Mardin Artuklu University School of Health, Mardin/TURKEY, Tel: +90 53250854 11; Fax: +90 048221269 47; Email: vasfiyedeg@gmail.com

\begin{abstract}
Objectives: This study was aimed to determine the RH/SH information levels of the 9th and 10th grade students attending at high schools and evaluate the effectiveness of the $\mathrm{RH} / \mathrm{SH}$ training program as well as the expectations of the students from the related services

Methods: Thedata were analyzed by using chi-square test, paired sample t-test, independent sample t-test and oneway variance analyses

Results: Before trainings, $54.9 \%$ of the students evaluated the discussion about RH/SH issues in the family as "taboo/never spoken".

Conclusions: Average knowledge scores of students according to discussing about RH/SH issues in the family" sub dimension were high

Keywords: Reproductive health; Sexual health; Education; Adolescent; Mardin/Kızlltepe; Turkey
\end{abstract}

\section{Introduction}

In all cultural, social, economic and political backgrounds and systemsaround the world, reproductive (RH) and sexual health (SH) needs of young individuals have been recognized as a part of healthy growth and development. (Aksu et al., 2008: 129-133) Nalbant and Bulut [1].The World Health Organization (WHO) defines the period between 10-19 ages as adolescence. In our country, the total population of $10-24$ age group is $19,779,000$ Karabulutlu and Kılıç [2]. Turkey Demographic and Health Survey (DHS) was administered in 2013 and it was found that the population aged between 10-24 formed 24.9\%of the general population. (Turkey Demographic and Health Survey, 2013: 390393)[3]. Since healthy habits, sexual health (SH)and reproductive health $(\mathrm{RH})$ behaviours began to be formed substantially during adolescence, the issues related to them need more attention (Turkey Demographic and Health Survey, 2013: 390-393)[3]. The SH and RH needs, problems and rights of the adolescents have been on the agenda for the last 25 years andthe unmet or undermet reproductive health needs are among the major public health challenges all over the world and also in Turkey.These unmet or undermet reproductive health needs result in unwanted pregnancies, adolescent pregnancies, non-hygienic abortions and sexually transmitted infections (STEM). Some of these health problems may cause irreversible harmsGiray and Kilic [4]; Tokuç et al. [5]. Protecting against these risks, especially those that develop into a separate economic and social problem for developing countries, is only possible with the right information and positive attitudes. The most effective, inexpensive and accessible way to do this is to provide ÜS / CS education in formal education Gürsoy and Gençalp [6]. Positive attitudes and having a high level of awareness are key to avoiding these risks that could become both a social and an economic challenge especially for developing countries. The most effective, inexpensive and accessible way to do this is to provide RH / SH training in formal education.The main purpose of sexual healthtraining isthat the adolescents'have freedom to organize their life with conscious choices, to take responsibility for their choices, to be pleased with their sexual identitywhile having a positive attitude to sexuality, andultimately to become mature individuals in the consciousness of their bodies and emotionsKaya et al. [7].

The issues related to $\mathrm{RH} / \mathrm{SH}$ are mostly ignored or very little information is shared in the formal education program. While the media could be used as an alternative source of information to enable young people to make informed decisions about their sexuality, it may cause adverse effects by giving false information from time to time Pınar et al. [8]. Most families are not open or ready to talking to their children on sexual issues because of traditional values, so the problems encountered by the adolescents in this period can be ignored by their families. All these factors lead to inadequate information on $\mathrm{RH} / \mathrm{SH}$ amongthe youths and may result insexually transmitted infections (STIs), adolescent pregnancies, curettage and complicated birthsPinar et al. [8] The formal education has been shown to improve general health 
and reduce the morbidity and mortality rates by many studies Karaoğlu and Pehlivan [9].Many studies have suggested that RH / SH education should be offered in secondary and high school Kaya et al. [7](Ozan et al., 2004: 27-39). Sexual health education appropriate for all ages should be provided Kaya et al. [7].The issues related to sexuality in Turkey remain as a challenge, and education, research and services on the subject is limited. It can not be said that the parents who are supposed to provide sexual education expected to be startedwithin the family lack sufficient knowledge in this regard. It is also known that sexual issues are still considered as a taboo due to social and cultural factors in our countrySet et al. [10].

For these reasons, sexual education programs targeted at the adolescent age groups should be made widespread Biri et al. [11]. The studies indicate that children and young people generally learn about sexuality from their peers and televisionrather than their family members in Turkey. For that reason, it is possible for the students to acquire healthy and correct information, skills and attitudes in such matters through the curricular activities in the schools. Both parents and schools often ignore the sexual needs of the children. The studies conducted on this subject have revealed that adolescents are willing to obtain this information especially at school, and that their parents and experts are particularly interested in the subject and want the relevant topics to be addressed in schools before puberty Pınar[12];Öztürk and Hazır Bıkmaz, [13].This study was aimed to determine the RH/ SH information levels of the 9th and 10th grade students attending at high schools in Kizıltepe district,Mardin, and evaluate the effectiveness of the $\mathrm{RH} / \mathrm{SH}$ training program as well as the expectations of the students from the related services.

\section{Method}

Mardin is one of the cities in Turkey's Southeastern Anatolia Region bordered by Syria WEB-1 [14]. Kizltepe is a district bordered by Mardin and Nusaybin from the east, Derik and Ceylanpınar from the west, Mazıdağ from the north and Syrian Arabian Republic from the south. The distance between Mardin and Kiziltepe is $13 \mathrm{~km}$. Away. The population of the district is 237,694 WEB 2 [15].This study was carried out among high school students in Kizlltepe district in Mardin province. After the necessary permission had been granted, the field work of this interventional study was done between February and May in 2015. The questionnaires were administered to the $9^{\text {th }}$ and $10^{\text {th }}$ grade students from the high schools in Kizlltepe city centre. The study procedure was followed by training on the issue and evaluation of the training provided using questionnaires again. A total of 19 high schools in Kizlltepe city center were excluded from the study because 3 of them were health vocational high schools. The final sampling of 16 schools surveyed were categorized into 3 groups (good-medium-poor)in view of admission examination scores and socio-economic levels. Six schools were identified, two schools selected from each group (good-moderate-poor) (Table 1). While selecting the schools, opinions of teachers and school administrators were taken into consideration and the schools including male and female students in equal or similar numbers were included in the study. The schools were chosen by deciding lots as the control and experimental group.

Table 1: Classification of the Study Groups.

\begin{tabular}{|c|c|c|c|c|c|}
\hline Study Group & Socioeconomic status & Names of the schools & Female & Male & Total \\
\hline \multirow{3}{*}{$\begin{array}{l}\text { Experimental } \\
\text { group }\end{array}$} & Good & Kizıltepe Anatolian High School & 200 & 167 & 367 \\
\hline & Moderate & Mesopotamia Anatolian High School & 241 & 200 & 441 \\
\hline & Poor & Kizıltepe Atatürk Anatolian High School & 235 & 377 & 612 \\
\hline \multicolumn{3}{|c|}{ Total } & 676 & 744 & 1420 \\
\hline \multirow{3}{*}{ Control Group } & Good & İpekyolu Anatolian High School & 232 & 207 & 439 \\
\hline & Moderate & Cumhuriyet Anatolian High School & 194 & 189 & 383 \\
\hline & Poor & Özcan Ylldız Religious Anatolian High School & 75 & 289 & 364 \\
\hline \multicolumn{3}{|c|}{ Control Group Total } & 501 & 685 & 1186 \\
\hline \multicolumn{3}{|c|}{ Experimental Group Total } & 1177 & 1429 & 2606 \\
\hline
\end{tabular}

\section{The Study Procedure is Explained Belowed}

The Study was Performed in 3 Phases: In the first phase, a three-part questionnaire (pre-test), which was developed depending on the literature in the classroom by the researcher under the supervision of the school counsellor, was administered to all the girls and boys in the $9^{\text {th }}$ and $10^{\text {th }}$ grades in 6 schools included in the experimental and control groups. In these schools, a participation form was sent to parents by the administration and the parents' consents were obtained. Before the questionnaire was administered, the aims of the study were explained to the students and their verbal consent was taken to participate in the survey.
The questionnaire was conducted in written on the same day and at the same time, under the control of the school teachers, in order to prevent the students from being influenced and transferring information to each other. The students were told that the answers they would give to the questions would be kept confidential and that they didn't have to answer all the questions without fail.In the second phase, the schools in the experimental group were visited 3 times for girls and boys separately. The training sessions were conducted simultaneously in separate halls, with girls and boys separated from each other.In the third phase, 3 months after the training sessions were completed, the questionnaires 
(post test) were re-administered to the students in the 6 schools (inlcuding both control and experimental groups) under the same conditions. Finally, the questionnaires were administered twice in each school, including the schools in which the training sessions were organized, and the schools in the control group, which were visited only once for administering the first questionnaire and never received any training session.

\section{Data Collection Tools}

The questionnaire consisted of 55 questions in total. The questions were prepared by the researcher in the light of the literature review. The questionnaire had 3 parts.The first part included 16 questions in order to obtain the socio-demographic characteristics of the students. The second part included questions about the students' views on reproductive health / sexual health information, whether they have had any previous training on the subject and whether the related issues are discussed in the family, etc. and there were 19 questions in total.The third part included 20 questions to evaluate students' knowledge levels on reproductive health / sexual health. Each correct answer was given 5 points and each incorrect answer or unanswered questions was given 0 points. The total knowledge score was evaluated out of 100.A pilot study was carried out before the research and the survey was finalized by making necessary corrections.The statistically significant increase in the mean score of the knowledge levels obtained after the study (out of 100 points) was considered as the criterion to consider that training was effective compared to the post-training level. These scores were evaluated separately in both the experiment and control groups following the post test.

The final sample included 2324 students (Response rate: was $89.0 \%$ ). The shortcomings of the study were that two students did not agree to participate in the survey during the study and the other students didn't attend the school regularly for various reasons (145 students in the experimental group, 135 students in the control group).The data were analyzed and evaluated using statistical package program. Means, median, percent, chi-square, Paired Sample t test, Independent Sample t test and One-way
ANOVA were used to analyze the variables. $p<0.05$ was accepted as statistical significance.

\section{Limitations of the Study}

Çalışma sonrası kontrol grubuna da eğitim verilmesi planlandı ancak okul idarecilerinin sıcak bakmaması üzerine uygulanamadı. The school administrators asked the researchers to complete the study quickly for fear that general educational processes may be interrupted for various reasons. Requests to extend the duration of the training were not accepted by the school administrators who insisted that the sessions should be completed within the scheduled time. The students were shy and sensitive during the training sessions. In the course of the training, there was a sharp reaction from only one female and one male student who did not want to participete in the study. A control group not involved in training sessions demanded to participate in the process. On account of the language problems of some of the students, it took a long time to read, understand and complete the questionnaire. In the last test (post test), multiple choice questions to be used instead of blank information questions could make it easier for the students to remember what they have learned. It was planned to provide training to the control group after the study but it could not be applied upon the rejection of the school administrators.

\section{Results}

The age median of the study sample ( $\mathrm{n}=2324)$ was 15 years (Min: 13, Max: 20). 54.1\% of the sample were male and $45.9 \%$ were female. Of the students in the experimental group (receiving training) were male $(50.4 \%)$ and female (\%49.6) while $58.6 \%$ were male and $41.4 \%$ were female in the control group (not receiving training). 59.8\% of the students were in the 9th grade and $40.2 \%$ were in the 10 th grade. The distribution of the students included in the survey according to the selected schools is illustrated in Table $10 \mathrm{f}$ the students surveyed in the study sample, $45.7 \%$ of their mothers were not literate and $97.6 \%$ of them had no job or income.56.3\% of the students' fathers had primary and lower level education, and $16.0 \%$ had no job or income (Table 2).

Table 2: Some Socio-Demographic Characteristics of the Students.

\begin{tabular}{|c|c|c|}
\hline Demographic variables & $\mathbf{n}$ & $\%$ \\
\hline \multicolumn{3}{|l|}{ Mother's educational level } \\
\hline Illiterate & 1062 & 45.7 \\
\hline Literate & 181 & 7.8 \\
\hline Primary school & 806 & 34.7 \\
\hline Secondary school & 202 & 8.7 \\
\hline High school and higher* & 73 & 3.1 \\
\hline \multicolumn{3}{|c|}{ Mother's job (being employed with salary) } \\
\hline Yes & 56 & 2.4 \\
\hline No & 2268 & 97.6 \\
\hline \multicolumn{3}{|l|}{ Father's Educational Level } \\
\hline Illiterate & 127 & 5.5 \\
\hline Literate & 166 & 7.1 \\
\hline
\end{tabular}




\begin{tabular}{|c|c|c|}
\hline Primary school & 1015 & 43.7 \\
\hline Secondary school & 493 & 16.3 \\
\hline High school & 378 & 6.2 \\
\hline University and higher & 145 & 84.0 \\
\hline Father's job (being employed with salary) & & 16.0 \\
\hline Yes & 1951 & 53.4 \\
\hline No & 373 & 37.2 \\
\hline Social insurance status & & \\
\hline SGK & 1240 & 9.5 \\
\hline None & 864 & 100.0 \\
\hline Private insurance & 220 & \\
\hline
\end{tabular}

Since the number of mothers who graduated from university was less than required $(n=15)$, they were included in high school and higher category.

Prior to the training procedure, $\% 79.6$ of the students included in the study sample responded "yes, I am" to the question " Are you aware of the changes to occur in your body in adolescence?". The responses of the experimental and control group are given below in Table $3.38 .5 \%$ of the students included in the survey stated that their teachers werethe major source of information about the subject in the pre-training. However, this rate was increased to $45.4 \%$ after the intervention (training). $37.2 \%$ of the students stated that they wanted to get the most information from the health staff in the pre-training about $\mathrm{RH} / \mathrm{SH}$ subjects. While $65.7 \%$ of the students thought that education should be provided about RH / SH subjects before the training, this rate was $78.0 \%$ in the post-training in the experimental group. $40.8 \%$ of the students included in the study sample stated that they wanted to receive training in all subjects related to $\mathrm{RH} / \mathrm{SH}$. The distribution of the opinions of the students about the subjects they want to receive training on $\mathrm{RH} / \mathrm{SH}$ according to the pre- and post-training, experimental and control group is shown in Table 4 below.

Table 3: Distribution of the Students' Responses Related to Some Variables Before and After Training Procedures.

\begin{tabular}{|c|c|c|c|c|}
\hline \multirow{2}{*}{ Knowledge level about changes in adolescence } & \multicolumn{2}{|c|}{ Before training } & \multicolumn{2}{|c|}{ After training } \\
\hline & $\mathbf{n}$ & $\%$ & $\mathbf{n}$ & $\%$ \\
\hline \multicolumn{5}{|l|}{ Experimental group $(n=1273)$} \\
\hline Good & 1025 & 80.5 & 1139 & 89.5 \\
\hline \multicolumn{5}{|l|}{ Control group $(n=1051)$} \\
\hline Poor & 825 & 78.5 & 865 & 82.3 \\
\hline \multicolumn{5}{|l|}{ Watching health programs on tv } \\
\hline \multicolumn{5}{|l|}{ Experimental group $(n=1273)$} \\
\hline Sometimes watching & 929 & 73.0 & 908 & 71.4 \\
\hline \multicolumn{5}{|l|}{ Control group $(n=1051)$} \\
\hline Sometimes watching & 770 & 73.3 & 726 & 69.1 \\
\hline \multicolumn{5}{|l|}{ Having taken health course } \\
\hline \multicolumn{5}{|l|}{ Experimental group $(n=1273)$} \\
\hline Yes & 613 & 48.2 & 496 & 39.0 \\
\hline \multicolumn{5}{|l|}{ Control group $(n=1051)$} \\
\hline Yes & 46.1 & 46.1 & 472 & 44.9 \\
\hline \multicolumn{5}{|l|}{ Having heard of RH/ SH concepts } \\
\hline \multicolumn{5}{|l|}{ Experimental group $(n=1273)$} \\
\hline Yes & 960 & 75.4 & 1157 & 90.9 \\
\hline \multicolumn{5}{|l|}{ Control group $(n=1051)$} \\
\hline Yes & 731 & 69.9 & 812 & 77.3 \\
\hline \multicolumn{5}{|l|}{ Discussin RH / SH subject within the family } \\
\hline \multicolumn{5}{|l|}{ Experimental group $(n=1273)$} \\
\hline It's a taboo/ never discussed & 703 & 55.2 & 559 & 43.9 \\
\hline
\end{tabular}


JOJ Nursing \& Health Care

\begin{tabular}{|c|c|c|c|c|}
\hline Always freely discussed & 38 & 3.0 & 32 & 2.5 \\
\hline Control group (n=1051) & & & 494 & 47.0 \\
\hline It's a taboo/ never discussed & 572 & 54.4 & 28 & 2.7 \\
\hline Always freely discussed & 28 & 2.7 & 2324 & 100.0 \\
\hline Total & 2324 & 100.0 & & \\
\hline
\end{tabular}

${ }^{*}$ There are more than one possible answer to the questions. The percentage werecalculated according to the frequencies.

Table 4: Distribution of The Opinions of the Students About the Subjects They Want to Receive Training on RH / SH Before And After Training.

\begin{tabular}{|c|c|c|c|c|}
\hline \multirow{2}{*}{ Opinions on the subjects* } & \multicolumn{2}{|c|}{ Before training } & A & After training \\
\cline { 2 - 5 } & $\mathbf{n}$ & & & \\
\hline Experimental group (n=1273) & & & 615 & 48.3 \\
\hline All of the subjects & 558 & 43.8 & 437 & 34.3 \\
\hline Symptoms of infection & 391 & 30.7 & 536 & 42.1 \\
\hline Genital hygiene & 345 & 27.1 & & 42.4 \\
\hline Control group (n=1051) & & & 446 & 37.4 \\
\hline All of the subjects & 390 & 37.1 & 393 & \\
\hline Symptoms of infection & 332 & 31.6 & 316 & \\
\hline Genital hygiene & 299 & 28.4 & & 30.1 \\
\hline
\end{tabular}

*There are more than one possible answer to the questions. The percentages were calculated according to the frequency.

The comparison of the pre-and post-training knowledge level mean scores according to the study group of the students included in the study are shown in Table 5.Comparisons of the pre-training knowledge level mean scores according to some demographic characteristics of the students in the study group are given in Table 6.Comparisons of the pre-and post-training knowledge level mean scores and testing differences according to the study group and grade levels of the students in the research group are shown in Table 7. The knowledge level mean scores of the students in the study group according to some variables before the training are shown in Table 8.The knowledge level mean scores of the students in the study group according towatching the health programs in the media before the training and the state of $\mathrm{RH} / \mathrm{SH}$ issues being discussed in the family before are given in Table 9.

Table 5: Comparison of Pre-Training and Post-Training Knowledge level mean scores of Students by Working Group.

\begin{tabular}{|c|c|c|c|}
\hline School group $(\mathbf{n}=\mathbf{2 3 2 4})$ & $\overline{\mathbf{x}} \pm \mathbf{s d}$ & $\mathbf{t}^{\mathbf{1}}$ & $\mathbf{P}$ \\
\hline Experimental group $(\mathbf{n = 1 2 7 3 )}$ & & -43.20 & $\mathbf{0 . 0 0 0 1}$ \\
\hline Before training & $19.35 \pm 13.00$ & & \\
\hline After training & $39.39 \pm 18.65$ & & $\mathbf{0 . 0 0 0 1}$ \\
\hline Control group $(\mathrm{n}=1051)$ & & -8.89 & \\
\hline Before training & $16.99 \pm 12.20$ & & \\
\hline After training & $20.20 \pm 13.73$ & & \\
\hline
\end{tabular}

*t test was used for the dependent group

Table 6: Comparisons of the Pre-Training Knowledge Level Mean Scores According to Some Demographic Characteristics of the Students.

\begin{tabular}{|c|c|c|c|}
\hline Descriptive characteristics (n=2324) & Before training & $\mathbf{t}^{*}$ & $\mathbf{P}$ \\
\hline Grade level & $\overline{\mathbf{x}} \pm \mathbf{s d}$ & 15.60 & $\mathbf{0 . 0 0 0 1}$ \\
\hline $9^{\text {th }}$ grade (n=1390) & & & \\
\hline $10^{\text {th }}$ grade (n=934) & $15.08 \pm 11.49$ & -3.39 & $\mathbf{0 . 0 0 1}$ \\
\hline Gender & $23.06 \pm 12.93$ & & \\
\hline Female (n=1066) & & & \\
\hline Male (n=1258) & $17.25 \pm 13.24$ & & \\
\hline Mother's job (being employed with salary) & & & \\
\hline Yes (n=56) & $21.74 \pm 13.27$ & & \\
\hline No (n=2268) & $18.20 \pm 12.68$ & & \\
\hline
\end{tabular}


JOJ Nursing \& Health Care

\begin{tabular}{|c|c|c|c|}
\hline Presence of living father & & -2.10 & $\mathbf{0 . 0 3 5}$ \\
\hline Living and together $(\mathrm{n}=2234)$ & $18.17 \pm 12.69$ & & \\
\hline Divorced or dead $(\mathrm{n}=90)$ & $21.05 \pm 12.71$ & & \\
\hline
\end{tabular}

*t test was used for the independent groups.

Table 7: Comparisons of the Pre-And Post-Training Knowledge Level Mean Scores And Testing Differences According to the Study Group And Grade Levels of the Students in the Research Group.

\begin{tabular}{|c|c|c|c|}
\hline \multirow{2}{*}{ School group } & Before training & After training & Test difference \\
\cline { 2 - 4 } & $\overline{\mathrm{x}} \pm \mathrm{sd}$ & $\overline{\mathrm{x}} \pm \mathrm{sd}$ & \\
\hline Experimental group $(\mathrm{n}=1273)$ & & & $21.13 \pm 16.07$ \\
\hline $9^{\text {th }}$ grade & $15.35 \pm 11.51$ & $36.46 \pm 17.67$ & $18.47 \pm 17.10$ \\
\hline $10^{\text {th }}$ grade & $25.06 \pm 12.90$ & $43.53 \pm 19.22$ & $2.83 / 0.005$ \\
\hline $\mathrm{t}^{*} / \mathrm{P}$ & $-14.08 / 0.000$ & $-6.75 / 0.000$ & $3.43 \pm 11.58$ \\
\hline $9^{\text {th }}$ grade & & & $2.84 \pm 11.86$ \\
\hline $10^{\text {th }}$ grade & $14.76 \pm 11.46$ & $18.20 \pm 12.95$ & $0.79 / 0.425$ \\
\hline $\mathrm{t}^{*} / \mathrm{P}$ & $20.49 \pm 12.52$ & $23.34 \pm 14.35$ & $-6.01 / 0.000$ \\
\hline
\end{tabular}

*t test was used for the independent groups.

Table 8: Comparison of the Knowledge Level Mean Scores of the Students in the Study Group According to Some Variables Before the Training.

\begin{tabular}{|c|c|c|c|}
\hline \multirow{2}{*}{ Some variables (n=2324) } & Before training & \multirow{2}{*}{ t* $^{*}$} & \\
\cline { 2 - 4 } & $\overline{\mathbf{x}} \pm \mathbf{s d}$ & & \\
\hline Being informed about the changes in adolescence & & & 0.23 \\
\hline Yes (n=1850) & $19.37 \pm 12.93$ & \\
\hline No (n=474) & $14.06 \pm 10.80$ & & 0.0001 \\
\hline Taking health course & & -10.05 & \\
\hline Yes (n=1226) & $20.74 \pm 13.13$ & \\
\hline No (n=1098) & $15.54 \pm 11.61$ & & \\
\hline Having heard of RH / SH concepts & & & 0.0001 \\
\hline Yes (n=1691) & $20.10 \pm 12.90$ & & \\
\hline No (n=13.44) & $13.44 \pm 10.74$ & & \\
\hline
\end{tabular}

${ }^{*} t$ test was used for the independent groups.

Table 9: The Knowledge Level Mean Scores of the Students in the Study Group According to Some Variables Before the Training.

\begin{tabular}{|c|c|c|c|}
\hline \multirow{2}{*}{ Some variables $(n=2324)$} & Before training & \multirow{2}{*}{$\mathbf{F}^{*}$} & \multirow{2}{*}{$\mathbf{P}$} \\
\hline & $\overline{\mathbf{x}} \pm \mathbf{s d}$ & & \\
\hline \multicolumn{4}{|l|}{ Watching health programs in media $(n=2324)$} \\
\hline Regularly watching $(\mathrm{n}=175)$ & $19.98 \pm 13.79$ & \multirow{3}{*}{2.06} & \multirow{3}{*}{0.127} \\
\hline Sometimes watching $(\mathrm{n}=1699)$ & $18.27 \pm 12.60$ & & \\
\hline Never watching $(\mathrm{n}=450)$ & $17.68 \pm 12.61$ & & \\
\hline \multicolumn{4}{|l|}{ Discussing RH / SH subjects in family $(\mathrm{n}=2324)$} \\
\hline It'a a taboo/never discussed ( $\mathrm{n}=1275)$ & $17.02 \pm 12.06$ & \multirow{4}{*}{9.92} & \multirow{4}{*}{0.0001} \\
\hline Implicitly discussed (n=307) & $20.60 \pm 13.25$ & & \\
\hline My family tolerates to me when I want to talk about RH / SH (n=676) & $19.46 \pm 13.33$ & & \\
\hline Always discussed freely $(n=66)$ & $19.81 \pm 12.99$ & & \\
\hline
\end{tabular}

*One way analysis of variance was used

\section{Discussion}

This study was carried out among high school students in Kizlltepe district of Mardin province in Turkey. There are many studies evaluating the knowledge levels on $\mathrm{RH} / \mathrm{SH}$ among high school students Karaoğlu and Pehlivan [9]; Aras et al. [16]; Aydoğan [17]; Savașer et al. [18]; Şimşek et al. [19]; Ege et al. [20] 
as well as university students Karabulutlu and Kılıç [2];Pınar et al. [8]; Pınar [11]; Aksu et al. [21]; Savaşer et al. [18]; Şimşek et al. [22]; Akın and Özvarış [23]; Aslan et al. [24]; Koluaçık et al. [25]; Akalpler [26]; Ünsal [27]; Demirtaş [28]; Oğuzkaya et al. [29]; Uzun and Kişioğlu [30]; Şerifhan İlgün et al. [31]; Akalpler and Eroğlu [32]; Siyez and Siyez [33]; Demir and Şahin [34]; Ok et al. [35]; Gölbaşı et al. [36]; Kılıç et al. [37], secondary school students Koyun et al. [38], primary school students Siyez [39]; Güler et al. [40];Demir and Şahin [41];Ok et al. [42]; Gölbaşı et al. [36] (Kilic et al., 2006), Koyun et al. [38]in primary school students Siyez [39]; Güler et al. [40] and parents (Kısa et al. 2013;Elikük and Sönmez [41];Tuğrul and Artan [42];Eroğlu and Gölbaşı [43];Akın et al. [44]; Aktoprak [45]. It is seen that there are a limited number of studies carried out in our country determining the knowledge levels on RH/SH of students compared to other countries.

$45.7 \%$ of the students included in the study didn't have literate mothers (Table 2). According to TDHS-2013 report, literacy rate among women is the lowest in Southeast Anatolia and the Eastern Anatolia regions (77\% and 84\%, respectively) (Turkey Demographic and Health Survey, 2013: 390-393). According to a study conducted in 2011, $43.1 \%$ of women are not literate,Bayram Değer [46]. The results of the study are well above the TDHS2013 results and overlap with the results of previous studies in the region. This shows that the education problem persists for the women living in the region. $97.6 \%$ of the students' mothers in the study group do not have a regular income. According to a study conducted in 2011 in the same region, only 5.1\% of the women are fully employed,Bayram Değer [46]. According to TDHS-2013 report, $20.9 \%$ of the women are currently employed in Southeastern Anatolia region (Turkey Demographic and Health Survey, 2013: 390-393). Being employed is an important indicator of women's empowerment like receiving education, and the results of the study are inferior to the results of both studies. $56.3 \%$ of the fathers' educational level of the students in the study group is at primary and lower level (Table 2). According to the TDHS-2013 report, 57.3\% of men's educational level in Southeast Anatolia region is at primary level or lower (Turkey Demographic and Health Survey, 2013: 390-393). It is seen from TDHS-2013 report that the men in the region also have educational problems, but their educational level is better than that of the women. $16.0 \%$ of the fathers of the students in the study group aren't fully employed (Table 2). According to Turkish Statistical Institute (TUIK) data, the unemployment rate in April 2016 was 9.3\% WEB 3 [47]. In a similar study conducted in 2005, the unemployment rate of the students' fatherwas 6.5\% (Güler et al. 2005) and the results of this study show that the unemployment rate in the region is higher than others.

About $79.6 \%$ of the students stated that they had adequate knowledge about the changes that occur in their bodies during adolescnece. This rate was $80.5 \%$ in the school selected as the experimental group and $78.5 \%$ in the control group (Table 3). In a study investigating the knowledge levels, attitudes and behaviors related to sexual health among students studying at a private university, $85.7 \%$ of them answered "I knew" when they were asked whether they knew about the changes that would occur in their bodies during adolescence (Pınar et al., 2009: 105113). In another study on the sexual attitudes and behaviors of the students of Dokuz Eylül University Facultyof Medicine, this rate was found as $76.5 \%$ for male students and $82.7 \%$ for female students Özan et al. [48]. In our study, it was determined that the rate of those who stated that they knew about the changes in their bodies in adolescence was high, but this rate was similar to the findings obtained byÖzan et al., however, these were lower than the findings of Pinar et al. It can be said that the students in the study group believe that they are conscious enough about the changes that will occur in their bodies during adolescence.

$73.1 \%$ of the students stated that they occasionally watched the health programs in the media before the training (Table 3). Considering the fact that some broadcasts and tv programs should be a source of information that enables young people to make informed decisions about their own sexuality while they can adversely affect young people, occasional use of mass media by the majority of students is seen as a positive result. However, it is surprising that they can not use the mass media effectively in relation to $\mathrm{RH} / \mathrm{SH} .54 .9 \%$ of the students in the study group described the state in which the concepts of RH / SH being discussed in the family before the training as "a taboo / never discussed" (Table 3). According to a study conducted among university students, $49.2 \%$ of the students stated that they can not talk about RH/ SH subjects with their mothers (Karabulutlu and Kılıç, 2011: 39-45). According to another study conducted among university students, this rate was found as $24.2 \%$ (Pınar, 2008: 6-44). In a study conducted in 2004, it was emphasized that the young people lack of information about the sexuality and the taboos related to the sexuality are suggested as the main reason for the issue (Giray and Kilic, 2004: 286-289). In the Factors Affecting the Sexual and Reproductive Health of Adolescents Project Report, $34.4 \%$ of the the students studying in the state university in Southeast Anatolia and in Central Anatolia regions were interviewed about discussing RH/ SH issues with their parents and the results showed that the rate was $13.4 \%$ among the students studying in Diyarbakır and 34.4\% in Ankara (Akın and Özvarıș, 2003: 10-41). Families living in the Southeastern Anatolia Region where the study was conducted are not open to talk with their children about sexual and reproductive health issues due to their traditional values, and the problems experienced by their children can be ignored. This may be due to the parents' inability to be well informed, their reluctance to speak, their embarrassment, their fear of losing their authority on their children. The increase in the rate at which the students can communicate with parents about the RH / SH issues after training can be considered as a predictor of the effectiveness of the training.

$38.5 \%$ of students included in the study stated that teachers were their major source of information related to $\mathrm{RH} / \mathrm{SH}$. This rate was $45.4 \%$ following the training procedure (Table 10 ). Similar to our findings, $93.1 \%$ of the university students ranked the 
teachers as their main source of information in a study carried out in Malatya .It was also reported in another study that $43.4 \%$ of the high school students in Istanbul considered their teachers (Eger et all., 2005: 2002-207; Savaşer et all., 2011: 1-8 ).Contrary to the findings of this study, in another study examining the knowledge levels of Cumhuriyet University students in Sivas province Özdemir et al.[49]it was found that television was considered as the main source of information aboutthe subject. In another study examining the knowledge levels about viral hepatitis among high school students Çelen et al. [50] it was also revealed that the television was the foremost source of information of students. Books, magazines and encyclopedias were found as the main sources of information among university students in Erzurum (3) , Ankara and Diyarbakır according to Affecting Sexual and Reproductive Health Factors Project report. Since peers, internet and mass media may make the teenagers misinformed about the subject, e the challenge here is much more important than ever. Since the teachers are seen as the main source of information, the health staff should help not only students but also the teachers and support the training sessions and consultancy in this regard. It is also especially important that primary health care services and school health nurses sholud work in a more active way to achieve that. $37.2 \%$ of the students in the study group stated that they wanted to get the most information from the health personnel before the training about $\mathrm{RH} / \mathrm{SH}$ subjects in both groups (Table 10). In a study conducted among university students in Malatya, it was found that the students considered the role of health staff before the training ashelping method selection (58.6\%) , and counseling (37.9\%) (Ege et al., 2005: 202-207). This similar situation may be due to the fact that sexuality issues are one of the unspoken subjects between the parents and the child, and the need to consult an expert. TheInformation provided by health personnel with sufficient knowledge may be considered as a significant contribution to the development of youth and community health.

While the rate of students who thought that the training on $\mathrm{RH} / \mathrm{SH}$ should be absolutely provided before the procedure was $65.7 \%$ before the training session, this was increased to $78.0 \%$ after the training (Table 10). Before the training on $\mathrm{RH} / \mathrm{SH}$, $51.3 \%$ of the students who participated in the study stated that the training should be provided in high school. There is a similarity in the literature with our findings that the students need a systematic training program on sexuality and reproductive health. (Akin et al., 2003: 10-41, Akin and Özvarıș, 2008: 6-44; , 2005: 202-207). The challenge about the training needs of the students in Turkey may also result from the fact that the information on sexuality and reproductive health in formal is generally limited to a unit in a course and often overlooked strarting from primary school to higher educational levels as well as these needs along with awareness increased by the training are more easily expressed.

Table 10: Distribution Of The Students' Responses Related to Some Variables Before and After Training Procedures.

\begin{tabular}{|c|c|c|c|c|}
\hline \multirow{2}{*}{ Sources of Information on $\mathrm{RH} / \mathrm{SH}^{*}$} & \multicolumn{2}{|c|}{ Before training } & \multicolumn{2}{|c|}{ After training } \\
\hline & n & $\%$ & n & $\%$ \\
\hline \multicolumn{5}{|l|}{ Experimental group $(n=1273)$} \\
\hline Teachers & 473 & 37.2 & 632 & 49.6 \\
\hline Peers & 442 & 34.7 & 455 & 35.7 \\
\hline \multicolumn{5}{|l|}{ Control group $(n=1051)$} \\
\hline Teachers & 421 & 40.1 & 424 & 40.3 \\
\hline Peers & 394 & 37.5 & 447 & 42.5 \\
\hline \multicolumn{5}{|l|}{ People to be consulted on $\mathrm{RH} / \mathrm{SH}^{*}$} \\
\hline \multicolumn{5}{|l|}{ Experimental group $(n=1273)$} \\
\hline Health staff & 510 & 40.1 & 599 & 47.1 \\
\hline Teachers & 370 & 29.1 & 512 & 40.2 \\
\hline Mothers & 331 & 26.0 & 277 & 21.8 \\
\hline \multicolumn{5}{|l|}{ Control group $(n=1051)$} \\
\hline Health staff & 355 & 33.8 & 431 & 41.0 \\
\hline Teachers & 318 & 30.3 & 395 & 37.6 \\
\hline Mothers & 283 & 26.9 & 255 & 24.3 \\
\hline \multicolumn{5}{|l|}{ Opinions on the necessity of training on $\mathrm{RH} / \mathrm{SH}$} \\
\hline \multicolumn{5}{|l|}{ Experimental group $(n=1273)$} \\
\hline Should be absolutely provided & 827 & 65.0 & 993 & 78.0 \\
\hline \multicolumn{5}{|l|}{ Control group $(n=1051)$} \\
\hline Should be absolutely provided & 700 & 66.6 & 775 & 73.7 \\
\hline \multicolumn{5}{|l|}{ Opinions on the timing of training on $\mathrm{RH} / \mathrm{SH}$} \\
\hline Experimental group $(n=1273)$ & & & & \\
\hline
\end{tabular}


JOJ Nursing \& Health Care

\begin{tabular}{|c|c|c|c|c|}
\hline Secondary school & 512 & 40.2 & 570 & 44.8 \\
\hline High school & 640 & 50.3 & 629 & 49.4 \\
\hline \multicolumn{5}{|l|}{ Control group $(n=1051)$} \\
\hline Secondary school & 370 & 35.2 & 401 & 38.2 \\
\hline High school & 552 & 52.5 & 566 & 53.9 \\
\hline \multicolumn{5}{|l|}{ Opinions on the quality of $\mathrm{RH} / \mathrm{SH}$ services* } \\
\hline \multicolumn{5}{|l|}{ Experimental group $(n=1273)$} \\
\hline The teenagers should know where to consult in case of necessity & 1192 & 93.6 & 1214 & 95.4 \\
\hline The services should be easily accessible and available & 1108 & 87.0 & 1146 & 90.0 \\
\hline Male counsellors should serve males and female counsellors should serve females & 1058 & 83.1 & 1043 & 81.9 \\
\hline \multicolumn{5}{|l|}{ Control group $(n=1051)$} \\
\hline The teenagers should know where to consult in case of necessity & 970 & 92.3 & 977 & 93.0 \\
\hline The services should be easily accessible and available & 877 & 83.4 & 922 & 87.7 \\
\hline Male counsellors should serve males and female counsellors should serve females & 851 & 81.0 & 823 & 78.3 \\
\hline \multicolumn{5}{|l|}{ Opinions on meeting information needs about $\mathrm{RH} / \mathrm{SH}^{*}$} \\
\hline \multicolumn{5}{|l|}{ Experimental group $(n=1273)$} \\
\hline $\begin{array}{l}\text { Male teachers should provide training for boys and female teachers should provide } \\
\text { training for girls in schools }\end{array}$ & 802 & 63.0 & 806 & 63.3 \\
\hline The health staff should provide training on the subject in schools & 780 & 61.3 & 924 & 72.6 \\
\hline \multicolumn{5}{|l|}{ Control group $(n=1051)$} \\
\hline $\begin{array}{l}\text { Male teachers should provide training for boys and female teachers should provide } \\
\text { training for girls in schools }\end{array}$ & 647 & 61.6 & 706 & 67.2 \\
\hline The health staff should provide training on the subject in schools & 637 & 60.6 & 579 & 55.1 \\
\hline Toplam & 2324 & 100.0 & 2324 & 100.0 \\
\hline
\end{tabular}

*There are more than one possible answer to the questions. The percentages were calculated according to the frequencies.

Before the training,93.6\% of the students who participated in the survey expressed their thoughts on the quality of RH / SH services in the following: 1) The young people should know where to consult about these topics, 2) The services should be easy to reach and readily available. 3) Male experts should serve males and female experts should serve females. In a study examining theknowledge levels on reproductive health and expectations from the services provided among İnönü University students, it was found that the students expressed their views in the following: 1) treatment and consultancy services should be accessible for everyone (\%73.2), 2) privacy should be maintained upon admission(\%61.9),3) Male experts should serve males and female experts should serve females (\%47.2) (Koluaçlk et all., 2010: 7-14). The inadequacy of social communication experience, ignorance about their bodies and where they can get help can often limit young people's access to the services they need. Health facilities are often inadequate for young people in view of RH / $\mathrm{SH}$ information, counseling and service delivery. The results of this study and the other one carried out in İnönü University indicated that the students have a lack of information on access to the services in RH / SH subjects. The fact that providing services to men and women should be done by their same gender experts may have resulted from the cultural characteristics of the regions studied.61.9\% of the students in the study group stated that the best way to meet the related information needs on $\mathrm{RH} / \mathrm{SH}$ is to provide training for female students by female instructors and male instructors for male students (Table 10). In a study conducted among university students in Malatya İnönü University on the knowledge levels about reproductive health issues and the their expectations from the services, it has been stated that providing services to men and women should be done by their same gender experts.(Koluaçık et al., 2010: 7-14). This may be due to the fact that students feel that they can express their problems more easily to the same gender experts due to regional sensitivities and cultural characteristics of the students.

It was found that the students who live with their mothers, male students, those whose parents are undereducatedandwith low socioeconomic status were not able to speak about RH / SH subjects in the family ( $p<0.05$, see Table 11 ), In the literature, it has been found that the students whose mothers have primary and secondary level of education never talk about their sexual issues with their mothers (Karabulutlu and Kılıç, 2011: 39-45, Kaya et al., 2007: 441-448, Set et al., 2006: 137-141). Due to the regional and traditional family background, it can be considered that such issues can not be discussed within the family. It can also be said that the students who can not discuss about the RH / CS issues in the family can refer to other sources of information and can not have the right health behavior due to misinformation. 
Table 11: Comparison on the State of Discussing RH / SH Subjects Within Family According to Descriptive Characteristics of Students.

\begin{tabular}{|c|c|c|c|c|c|c|c|c|c|}
\hline \multirow{3}{*}{$\begin{array}{c}\text { Descriptive } \\
\text { characteristics }\end{array}$} & \multicolumn{9}{|c|}{ Discussing RH / SH subjects within family $(n=2324)$} \\
\hline & \multicolumn{2}{|c|}{$\begin{array}{l}\text { It'a a taboo/never } \\
\text { discussed }\end{array}$} & \multicolumn{2}{|c|}{ Implicitly discussed } & \multicolumn{2}{|c|}{$\begin{array}{l}\text { My family tolerates to } \\
\text { me when I want to talk } \\
\text { about RH / SH }\end{array}$} & \multicolumn{2}{|c|}{$\begin{array}{l}\text { Always discussed } \\
\text { freely }\end{array}$} & $\mathrm{X} 2 / \mathrm{p}$ \\
\hline & $\mathbf{n}$ & $\%$ & $\mathbf{n}$ & $\%$ & n & $\%$ & n & $\%$ & \multirow{4}{*}{$10.170 / 0.017$} \\
\hline \multicolumn{9}{|l|}{$\begin{array}{l}\text { Presence of living } \\
\text { mother }\end{array}$} & \\
\hline Living and together & 1258 & 55.0 & 304 & 13.3 & 663 & 29.0 & 62 & 2.7 & \\
\hline Divorced or dead & 17 & 45.9 & 3 & 8.1 & 13 & 35.1 & 4 & 10.8 & \\
\hline \multicolumn{10}{|l|}{ Gender } \\
\hline Female & 447 & 41.9 & 165 & 15.5 & 415 & 38.9 & 39 & 3.7 & \multirow{2}{*}{$137.919 / 0.0001$} \\
\hline Male & 828 & 65.8 & 142 & 11.3 & 261 & 20.7 & 27 & 2.1 & \\
\hline \multicolumn{10}{|l|}{$\begin{array}{c}\text { Mother's educational } \\
\text { level }\end{array}$} \\
\hline Illiterate & 629 & 59.2 & 137 & 12.9 & 272 & 25.6 & 24 & 2.3 & \multirow{5}{*}{$37.093 / 0.0001$} \\
\hline Literate & 94 & 51.9 & 33 & 18.2 & 50 & 27.6 & 4 & 2.2 & \\
\hline Primary school & 429 & 53.2 & 108 & 13.4 & 244 & 30.3 & 25 & 3.1 & \\
\hline Secondary school & 92 & 45.5 & 23 & 11.4 & 78 & 38.6 & 9 & 4.5 & \\
\hline High school & 31 & 42.5 & 6 & 8.2 & 32 & 43.8 & 4 & 5.5 & \\
\hline \multicolumn{10}{|l|}{$\begin{array}{c}\text { Father's educational } \\
\text { level }\end{array}$} \\
\hline Illiterate & 74 & 58.3 & 14 & 11.0 & 36 & 28.3 & 3 & 2.4 & \multirow{6}{*}{$51.891 / 0.0001$} \\
\hline Literate & 107 & 64.5 & 23 & 13.9 & 30 & 18.1 & 6 & 3.6 & \\
\hline Primary school & 583 & 57.4 & 147 & 14.5 & 266 & 26.2 & 19 & 1.9 & \\
\hline Secondary school & 256 & 51.9 & 63 & 12.8 & 154 & 31.2 & 20 & 4.1 & \\
\hline High school & 187 & 49.5 & 51 & 13.5 & 124 & 32.8 & 16 & 4.2 & \\
\hline University or higher & 68 & 46.9 & 9 & 6.2 & 66 & 45.5 & 2 & 1.4 & \\
\hline \multicolumn{10}{|l|}{ Family income } \\
\hline Very poor & 23 & 52.3 & 7 & 15.9 & 13 & 29.5 & 1 & 2.3 & \multirow{5}{*}{$25.691 / 0.012$} \\
\hline Poor & 147 & 60.0 & 32 & 13.1 & 64 & 26.1 & 2 & 0.8 & \\
\hline Moderate & 771 & 56.8 & 172 & 12.7 & 379 & 27.9 & 36 & 2.7 & \\
\hline High & 320 & 50.2 & 85 & 13.3 & 208 & 32.6 & 25 & 3.9 & \\
\hline Very high & 14 & 35.9 & 11 & 28.2 & 12 & 30.8 & 2 & 5.1 & \\
\hline Total & 1275 & 54.9 & 307 & 13.2 & 676 & 29.1 & 66 & 2.8 & \\
\hline
\end{tabular}

The pre-training and post-training knowledge level mean scores of the students were found to be higher ( $\mathrm{p}<0.05$, see Table 5).In another study on the effectiveness of the sexual and reproductive health training program developed for the university students, it was determined that the experimental group had higher scores than the control group at the end of RH /SH training (Pinar, 2008: 6-44). According to a study on the evaluation of the effectiveness of family planning training among midwifery senior students in 2005, the knowledge level of the students following the training was found to be high (Ege et al., 2005: 202-207). It can be suggested that the students in the intervention group included in the survey had a high level of knowledge level scores following thre training and thetraining session was effective indeed(Table 12).
Table 12: Distribution of the Students According to the Selected Schools.

\begin{tabular}{|c|c|c|}
\hline Schools & n & \% \\
\hline Experimental group (n=1273) & & \\
\hline Kizlltepe Anatolian High School & 329 & 14.2 \\
\hline Mesopotamia Anatolian High School & 452 & 19.4 \\
\hline Kizlltepe Atatürk Anatolian High School & 492 & 21.2 \\
\hline Control group (n=1051) & & \\
\hline İpekyolu Anatolian High School & 375 & 16.1 \\
\hline Cumhuriyet Anatolian High School & 366 & 15.7 \\
\hline Özcan Ylldız Religious Anatolian High School & 310 & 13.3 \\
\hline Total & 2324 & 100.0 \\
\hline
\end{tabular}




\section{JOJ Nursing \& Health Care}

Those who were aware of the changes that would occur in their body during adolescence,tookhealth courses in school and heard about RH/ SH concepts were found to have a higher knowledge level mean scores ( $\mathrm{p}<0.05$,see Table 8 ). The students' background and the training provided can enhance the chance of success. Therefore, students' theoretical knowledge and the displaying the right health behaviors may increase this chance. In this study, the knowledge level mean scores were found to be higher according to the state of the students'discussing about RH/ SH issues in the family ( $p<0.05$,see Table 9). In the literature, it has been found that the students can not speak about thesel issues with their family (Karabulutlu and Kılıç, 2011: 39-45; Kaya et al., 2007: 441-448; Set et al., 2006: 137-141). It can also be said that the students who can not discuss about the RH / CS issues in the family can refer to other sources of information and can not have the right health behavior due to misinformation(Table 13).

Table 13: Distribution of the Opinions of the Students on İnformation Questions Before and After Training on RH / SH.

\begin{tabular}{|c|c|c|c|c|}
\hline \multirow{2}{*}{ Information questions on RH / SH $(n=2324)$} & \multicolumn{2}{|c|}{ Eğitim Öncesi } & \multicolumn{2}{|c|}{ Eğitim Sonrası } \\
\hline & Sayı & $\%$ & Sayı & $\%$ \\
\hline \multicolumn{5}{|l|}{ Genital and anal hygiene habits } \\
\hline \multicolumn{5}{|l|}{ Experimental group(n=1273) } \\
\hline front to back & 320 & 25.1 & 645 & 50.7 \\
\hline unknown & 953 & 74.9 & 628 & 49.3 \\
\hline \multicolumn{5}{|l|}{ Control Group(n=1051) } \\
\hline front to back & 279 & 26.5 & 267 & 25.4 \\
\hline unknown & 772 & 73.5 & 784 & 74.6 \\
\hline \multicolumn{5}{|c|}{ Responses related to the ways of avoiding sexually transmitted diseases (STDs) } \\
\hline \multicolumn{5}{|l|}{ Experimental group(n=1273) } \\
\hline Knowing one way of avoiding STDs & 53 & 4.2 & 123 & 9.7 \\
\hline Knowing two ways of avoiding STDs & 10 & 0.8 & 166 & 13.0 \\
\hline Not knowing & 1210 & 95.0 & 984 & 77.3 \\
\hline \multicolumn{5}{|l|}{ Control Group(n=1051) } \\
\hline Knowing one way of avoiding STDs & 23 & 2.1 & 27 & 2.6 \\
\hline Knowing two ways of avoiding STDs & 9 & 0.9 & 7 & 0.7 \\
\hline Not knowing & 1019 & 97.0 & 1017 & 96.7 \\
\hline \multicolumn{5}{|l|}{ Responses related to the diagnosis of AIDS } \\
\hline \multicolumn{5}{|l|}{ Experimental group(n=1273) } \\
\hline Using blood test & 426 & 33.5 & 643 & 50.5 \\
\hline Not knowing & 847 & 66.5 & 630 & 49.5 \\
\hline \multicolumn{5}{|l|}{ Control Group(n=1051) } \\
\hline Using blood test & 261 & 24.8 & 323 & 30.7 \\
\hline Not knowing & 790 & 75.2 & 728 & 69.3 \\
\hline \multicolumn{5}{|l|}{ Responses related to the spreading ways of AIDS } \\
\hline \multicolumn{5}{|l|}{ Experimental group(n=1273) } \\
\hline Knowing one way of spreading & 197 & 15.5 & 285 & 22.4 \\
\hline Knowing two ways of spreading & 78 & 6.1 & 253 & 19.9 \\
\hline Not knowing & 998 & 78.4 & 735 & 57.7 \\
\hline \multicolumn{5}{|l|}{ Control Group $(n=1051)$} \\
\hline Knowing one way of spreading & 123 & 11.7 & 150 & 14.3 \\
\hline Knowing two ways of spreading & 26 & 2.5 & 43 & 4.1 \\
\hline Not knowing & 902 & 85.8 & 858 & 81.6 \\
\hline \multicolumn{5}{|l|}{ Responses related to the treatment of AIDS } \\
\hline \multicolumn{5}{|l|}{ Experimental group $(n=1273)$} \\
\hline Untreatable & 157 & 12.3 & 402 & 31.6 \\
\hline Not knowing & 1116 & 87.7 & 871 & 68.4 \\
\hline Control Group(n=1051) & & & & \\
\hline
\end{tabular}




\begin{tabular}{|c|c|c|c|c|}
\hline Untreatable & 119 & 11.3 & 148 & 14.1 \\
\hline Not knowing & 932 & 88.7 & 903 & 85.9 \\
\hline \multicolumn{5}{|c|}{ Responses related to the family planning } \\
\hline \multicolumn{5}{|l|}{ Experimental group(n=1273) } \\
\hline Defining correctly & 85 & 6.7 & 268 & 21.1 \\
\hline Not knowing & 1188 & 93.3 & 1005 & 78.9 \\
\hline \multicolumn{5}{|l|}{ Control Group(n=1051) } \\
\hline Defining correctly & 55 & 5.2 & 82 & 7.8 \\
\hline Not knowing & 996 & 94.8 & 969 & 92.2 \\
\hline \multicolumn{5}{|c|}{ Responses related to the family planningmethods } \\
\hline \multicolumn{5}{|l|}{ Experimental group(n=1273) } \\
\hline Knowing one method & 8 & 0.6 & 17 & 1.3 \\
\hline Knowing two methods & 3 & 0.2 & 122 & 9.6 \\
\hline Not knowing & 1262 & 99.2 & 1134 & 89.1 \\
\hline \multicolumn{5}{|l|}{ Control Group(n=1051) } \\
\hline Knowing one method & 1 & 0.1 & 2 & 0.2 \\
\hline Knowing two methods & 2 & 0.2 & 11 & 1.0 \\
\hline Not knowing & 1048 & 99.7 & 1038 & 98.8 \\
\hline
\end{tabular}

\section{Conclusion}

\section{The Results of the Study Can be Summarized as in the Following}

High school students in Kizlltepe District of Mardin Province were found to have an increase in the mean scores of knowledge level in both intervention and control groups following the training. The knowledge level score means in the intervention group were found to be moderate and low in the control group(Table 14).

\section{The Following Recommendations Could be Put Forward based on the Results of the Study}

i. In order for the students living among traditional communities to be able to talk with their parents about sexual / reproductive health issues, their parents should be included in the training programs at first. ii. "Youth Solidarity Center" or "Reproductive Health Center" units in schools within the framework of increasing the availability of services for sexual health / reproductive health should be founded.

iii. Efforts to increase access to sexual / reproductive health services should be encouraged,

iv. Sexuality training through systematic programs within the formal educational system in the pre-university basic educational period should be launched,

v. Curriculum programs addressing the needs of different age groups should be prepared,

vi. The results of the research can be shared with Ministry of National Education and the training programs for the region in line with the study results should be designed and implmented.

Table 14: Comparison on the State of Being Informed About Future Changes in the Period of Adolescence According to Descriptive Characteristics of Students.

\begin{tabular}{|c|c|c|c|c|c|}
\hline \multirow{3}{*}{ Descriptive characteristics } & \multicolumn{4}{|c|}{ State of Being Informed about Changes in Adolescence } & \multirow{2}{*}{$\mathrm{X} 2 / \mathrm{p}$} \\
\hline & \multicolumn{2}{|c|}{ Informed } & \multicolumn{2}{|c|}{ Uninformed } & \\
\hline & $\mathbf{n}$ & $\%$ & $\mathbf{n}$ & $\%$ & \multirow{4}{*}{$12.371 / 0.0001$} \\
\hline \multicolumn{5}{|l|}{ Grade level } & \\
\hline $9^{\text {th }}$ grade & 1073 & 77.2 & 317 & 22.8 & \\
\hline $10^{\text {th }}$ grade & 777 & 83.2 & 157 & 16.8 & \\
\hline \multicolumn{5}{|l|}{ Gender } & \\
\hline Female & 876 & 82.2 & 190 & 17.8 & \multirow{2}{*}{$8.025 / 0.005$} \\
\hline Male & 974 & 77.4 & 284 & 22.6 & \\
\hline Father's educational level & & & & & \\
\hline
\end{tabular}




\begin{tabular}{|c|c|c|c|c|c|}
\hline Illiterate & 102 & 80.3 & 25 & 19.7 & \multirow{6}{*}{$12.710 / 0.026$} \\
\hline Literate & 143 & 86.1 & 23 & 13.9 & \\
\hline Primary school & 779 & 76.7 & 236 & 23.3 & \\
\hline Secondary school & 396 & 80.3 & 97 & 19.7 & \\
\hline High school & 307 & 81.2 & 71 & 18.8 & \\
\hline University or higher & 123 & 84.8 & 22 & 15.2 & \\
\hline \multicolumn{6}{|l|}{ Social insurance } \\
\hline None & 667 & 77.2 & 197 & 22.8 & \multirow{3}{*}{$5.361 / 0.069$} \\
\hline SGK & 1001 & 80.7 & 239 & 19.3 & \\
\hline Private insurance & 182 & 82.7 & 38 & 17.3 & \\
\hline \multicolumn{6}{|l|}{ Family income } \\
\hline Very poor & 30 & 68.2 & 14 & 31.8 & \multirow{5}{*}{$15.906 / 0.003$} \\
\hline Poor & 175 & 71.4 & 70 & 28.6 & \\
\hline Moderate & 1098 & 80.9 & 260 & 19.1 & \\
\hline High & 517 & 81.0 & 121 & 19.0 & \\
\hline Very high & 30 & 76.9 & 9 & 23.1 & \\
\hline \multicolumn{6}{|l|}{ Taking health course $(n=2324)$} \\
\hline Yes & 855 & 77.9 & 243 & 22.1 & \multirow{2}{*}{$3.860 / 0.049$} \\
\hline No & 995 & 81.2 & 231 & 18.8 & \\
\hline \multicolumn{6}{|l|}{ Watching health programs on tv or media $(n=2324)$} \\
\hline Regularly watching & 135 & 77.1 & 40 & 22.9 & \multirow{3}{*}{$5.205 / 0.074$} \\
\hline Sometimes watching & 1372 & 80.8 & 327 & 19.2 & \\
\hline Never watching & 343 & 76.2 & 107 & 23.8 & \\
\hline \multicolumn{6}{|l|}{ Discussing RH / SH subjects within family $(\mathrm{n}=2324)$} \\
\hline It'a a taboo/never discussed & 979 & 76.8 & 296 & 23.2 & \multirow{4}{*}{$14.758 / 0.002$} \\
\hline Implicitly discussed & 258 & 84.0 & 49 & 16.0 & \\
\hline My family tolerates to me when I want to talk about RH / SH & 561 & 83.0 & 115 & 17.0 & \\
\hline Always discussed freely & 52 & 78.8 & 14 & 21.2 & \\
\hline Total & 1850 & 79.6 & 474 & 20.4 & \\
\hline
\end{tabular}

\section{References}

1. Nalbant H, Bulut (2001) Youth and Reproductive Health. Actual Medical Journal Special Number of Women's Health 6(1): 30-36.

2. Karabulutlu Ö, Kılıç M (2011) Determination of Knowledge Levels about Sexual Health and Reproductive Health of University Students. Anadolu Nursing and Health Sciences Journal 14(2): 39-45.

3. Turkey Demographic and Health Survey (2013) Ankara: Hacettepe University Institute of Population, T. C. Ministry of Development and TUBITAK.

4. Giray H, Kılıç B (2004) Single Women and Reproductive Health. STED 13(8): 286-289.
5. Tokuç B, Berberoğlu B, Saraçoğlu GV, Çelikkalp Ü (2011) Opinions of School of Health Students on Non-Marriage Sexual Relationship, Voluntary Abortions and Contraceptive Use. Turkey Journal of Public Health 9(3): 166-173.

6. Gürsoy E, Gençalp NS (2010) The Importance of Sexual Health Education. Family and Society, p. 29-36.

7. Kaya F, Serin Ö, Genç A (2007) The Determination of Approaches to the Sexual Life of Primary School Students in the Faculty of Education. TAF Preventive Medicine Bulletin 6(6): 441-448.

8. Pınar G, Doğan N, Ökdem Ş, Algıer L, Öksüz E (2009) Knowledge, Attitudes and Behaviors Related to Sexual Health of Students Reading in a Private University. Journal of Medical Research 7(2): 105-113. 
9. Karaoglu L, Pehlivan E (1997) Investigation of Information, Attitudes and Practices Related to Health Related to Senior High School Students in Different Programs in Malatya City Center. Journal of Turgut Ozal Medical Center 4(4): 391-398.

10. Set T, Deployer N, Aktürk Z (2006) Sexuality in adolescents. General Medical Journal 16(3): 137-141.

11. Biri A, Korucuoğlu Ü, Yllmaz E, Ark (2007) Determination of Sexual Knowledge Needs of Adolescent Girls. Turkish Journal of Obstetrics and Gynecology 4(2): 104-107.

12. Pınar G (2008) The Effectiveness of the Sexual Health and Reproductive Health Education Program for University Youths, Doctorate Thesis. Hacettepe University Institute of Health Sciences, Ankara, p. 6-44.

13. OztürkDSG, Hazır Bıkmaz F (2007) İn Primary Health Awareness Program: An Integrated Approach to Content Analysis in Health Framework. Ankara University Faculty of Educational Sciences 40(1): 215-242.

14. WEB 1 Mardin. You.

15. WEB 2 Kızıltepe, Mardin.

16. Aras S, Şemin S, Günay T, Orçun E, Ozan S (2005) Sexual Attitude and Behavioral Characteristics of High School Students. Turkish Pediatry Archives 40: 72-82.

17. Aydogan I (2011) Problems of Girl Learners in General High School. Family and Society 7(24): 47-68.

18. Savașer S, Balcı S, Ceylan N (2011) Awareness of High School Students towards Hepatitis B Disease and Protection from Disease. Istanbul University Florance Nightingale Nursing Journal 19(1): 1-8.

19. Şimşek Ç, Piyal B, Tüzün H (2010) Personal Hygiene Behaviors in Some High School Students in. TAF Preventive Medicine Bulletine 9(5): 443 440

20. Ege E, Timur S, Zincir H (2005) Evaluatıon Of Effıcıency Of Educatıonal Famıly Plannıng Educatıon In Middle Early Students. Sted 14(9): 202 207.

21. Aksu H, Karagöz B, Ergin F (2008) Examination of Knowledge Levels of Sexual Health / Reproductive Health of University Students and the Effectiveness of the Education Provided. Continuing Medical Education Journal 17(10): 129-133.

22. Simșek Z, Koruk İ, Altındağ A (2008) Risk Health Behaviors of First Grade Students at Harran University Faculty of Medicine and Science and Literature Faculty. Bulletin of Community Medicine 26(3): 19-24.

23. Akın A, ÖzvarıșŞB (2003) Factors Affecting the Sexual and Reproductive Health of Adolescents (Report). Ankara, p. 10-41.

24. Aslan E, Bektaş H, Başgöl S, Demir S, Irmak Vural P (2014) Knowledge Levels and Behaviors of Sexual Health in University Students. STED 23(5): 174-182.

25. Koluaçık S, Güneş G, Pehlivan E (2010) İnönü University Students' Knowledge Levels on Reproductive Health and Their Expectations from the Service. Inonu University Medical.

26. Akalpler Ö (2010) Information and Sexual Behaviors of Common Sexually Transmitted Infections of University Students, Master Thesis. Near East University Institute of Health Sciences, p. 9-31.

27. Ünsal A (2010) Genital Hygiene Behaviors of Girl Students Reading in University. Firat Health Services Journal 5(13): 80-93.

28. Demirtaș B (2006) Determination of Vulva Health Information of Nursing Students. Hacettepe Nursing High School Magazine, p. 14-25.

29. Oğuzkaya Artan M, Güleser NG (2006) Students of the School of Health HIV / AIDS, Hepatitis B Virus and Hepatitis C Virus Assessment of Knowledge levels. Erciyes Medical Journal 28(3): 125-133.
30. Uzun E, Kişioğlu M (2007) S.D.U. Faculty of Medicine Department of Public Health Education and Research Area Studies Keçiborlu, STD Students who read at a Vocational School 's Status of Related Information. SDÜ, Faculty of Medicine Journal 14(3): 7-12.

31. Şerifhan İlgün M, Erbay Dündar P, Doğramacı YG, Dalcı A, Gürgen G (2005) The Family Planning of a Group of Learners at Celal Bayar University and the Levels of Knowledge on STD. TAF Preventive Medicine Bulletin 4(2): 66-78.

32. Akalpler Ö, Eroğlu K (2015) Information Levels and Sexual Behaviors of Common Sexually Transmitted Infections of University Students in Turkish Republic of Northern Cyprus. Hacettepe University Journal of Nursing Faculty, p. 1-19.

33. Siyez DM, Siyez E (2009) Examination of Knowledge Levels of University Students about STDs. Turkish Journal of Urology 35(1): 4955.

34. Demir G, Sahin TK (2014) Information on Sexually Transmitted Diseases of Selcuk University Students. Düzce University Journal of Health Sciences Institute 4(3): 19-24.

35. Ok Ş, Zincir H, Ege E (2002) Inonu University Health Services Vocational School of Nursing and Midwifery Program Students of STD 's some information about the Evaluation of Factors Affecting it. Inonu University Medical Faculty Journal 9(1): 59-63.

36. Gölbaşı Z, Çetin R, Kalkan S, Durmuş T (2010) Knowledge and Behaviors of University Students Girls about Breast Examination. The Journal of Breast Health 6(2): 69-73.

37. Kılıç S, Uçar M, Seymen E (2006) Investigation of Self Breast Examination Information and Practice on Gynecologic Nurses, Nursing Students and Gynecologic Patients in GATA Training Hospital. Gülhane Medical Journal 48: 200-204.

38. Koyun A, Özpulat F, ÖzvarıșŞB (2013) Development and Evaluation of a Training Program: 'Genital Hygiene' Training Program for Secondary Girls' Students. Gümüșhane University Journal of Health Sciences 2(4): 443-459.

39. Siyez DM (2009) Examination of Knowledge Levels and Attitudes Towards Adolescence and Sexual Health of the Students Going to the Fourth Grade Elementary School. Contemporary Education Journal 34(369): 17-26.

40. Güler G, Bekâr M, Güler N, Kocataş S (2005) Menstrual period hygiene in primary school girl students. STED 14(6): 135-139.

41. Eliküçük A, Sönmez S (2011) The Investigation of Parental Opinions Related to Sexual Development and Education of 6-Year-Old Children. Family and Society, p. 45-62.

42. Tuğrul B, Artan I (2001). An Investigation of Maternal Opinions on Sexual Education of Children. Hacettepe University Journal of Education Faculty 20: 141-149.

43. Eroğlu K, Gölbaşı Z (2005) What do parents do in sexual education and what do they live?. Journal of Atatürk University Nursing School 8(2): $12-21$.

44. Akın L, Özaydın N, Aslan D (2006) Factors Affecting the Use of Family Planning Methods of Married Men in Turkey. Gülhane Medical Journal 48: 63-69.

45. Aktoprak M (2012) Attitudes of Married Women and Their Families Towards Family Planning and Related Factors, Master Thesis. University of Selcuk Institute of Health Sciences Department of Nursing, Department of Obstetrics and Gynecology Nursing, Konya 3: 3.

46. Bayram Değer V (2011) Mothers and Babies in the Postnatal Age of Married Women Living in Kiziltepe District of Mardin and / or Conventional Methods for Their Application, Master Thesis. Firat University Health Sciences Institute. Elazığ, pp. 77-110. 
47. Özdemir L, Ayvaz A, Poyraz Ö (2003). The Knowledge Level of Students of Cumhuriyet University on Sexually Transmitted Diseases. Cumhuriyet University Medical Faculty Journal 25(1): 10-14.

48. WEB 3 TURKSTAT Key Indicators, Unemployment Rate.

49. Özan S, Aras S, Semin S, Orçin E (2003) Sexual Attitude and Behavioral Characteristics of the Students of Dokuz Eylül University Medical
Faculty. Journal of Dokuz Eylül University Faculty of Medicine 18(1): 27-39.

50. Çelen MK, Ayaz C, Geyik MF, Hoșoğlu S, Acemoglu H, Ulug M (2005) Knowledge Levels of High School Students About Viral Hepatitis. Viral Hepatitis Journal 10(1): 58-61.

\section{Your next submission with Juniper Publishers will reach you the below assets}

- Quality Editorial service

- Swift Peer Review

- Reprints availability

- E-prints Service

- Manuscript Podcast for convenient understanding

- Global attainment for your research

- Manuscript accessibility in different formats

(Pdf, E-pub, Full Text, Audio)

- Unceasing customer service

Track the below URL for one-step submission https://juniperpublishers.com/online-submission.php 